\title{
CHEMISTRY WEB EDUCATION: IMPROVING OF USERS' LEARNING ACTIVITIES
}

\author{
Marat Akhmetov \\ Teacher Professional Skills Advancement Institute, \\ Ulyanovsk, Russia
}

\begin{abstract}
Web education today is becoming increasingly popular. More and more students use the Web for searching information about substances and chemical reactions, but only little part of websites users is able to achieve success in learning chemistry. Free web education has both advantages and disadvantages. Students can study at their own pace and at a convenient time, but they need ability to do exercises without teachers' support. Our research let us understand what a web teacher can do for students' success in learning chemistry.

It is hard to study chemistry for many students, because chemistry is a special part of human knowledge. For success in learning chemistry students must have amount of chemical knowledge. Students should understand chemical phenomenon, chemical formulas, and structures of substances. They should have ability to solve chemical problems.

We studied educational materials on the most popular Russian-language chemical education websites. Results and discussion are presented in this paper. It has shown what educational websites should publish useful chemical information for students. They should have opportunity to answer any chemical questions and discuss chemical problems with other users. A Web teacher must put information on a website which can improve students' interest in chemistry. Chemical information should relate life situations, a history of chemistry, mass-media and other sides of human life. Web teacher should put multimedia chemical information, not only formulas, equation, but pictures, audio and video on a website. This information is very interested for students and prepares their chemical knowledge and their success. As a result of useful and interested information they should want to visit a website again.
\end{abstract}

Key words: learning activities, chemical education, websites.

\section{Introduction}

The $21^{\text {st }}$ century is the time of informational and communicated technologies. We have today a lot of information from many sources: from papers, magazines, books, TV, from the Internet too. People need ability to information processing. New time dictates new purposes of education. There are graduates' learning activities, graduates' ability to study through their lives, their wishes for self-education, graduates' desires to develop their own skills. Students today have education not only at the classroom. World Wide Web became more popular for educational goals. The Internet is not education only. The Internet includes much useless and harmful information. How to defend users from negative information? We have the answer to this question. As we suppose users need learning activity. The problem of our research is finding ways to improve learning activity of users on chemical education websites.

There are two points of view on concepts of learning activities. In conformity with first point of view learning activities are classroom activities. In conformity with second 
concept learning activities is individual characteristic, an intention to study. Russian psychologists T. Shamova, G. Shchukina supposed what learning activities as characteristic of personality include three levels. First level is reproducing activity, because students need chemical information, understanding and skills that they gain through studying. If students have some knowledge of chemistry they can solve simple chemical problems. Therefore they achieve second level - interpretative activity. The third level is a creative activity. Creative activity is ability to find new way to solve chemical problems. This level students have strong will, ability to self-education and self-regulation. They've get joy, success, satisfaction through learning.

If students through their education have only reproducing activity, they can't achieve creative activity at the end of secondary school. Therefore students need first, second and third levels of learning activities in each chemical topic. At the beginning of study chemistry learning activities is classroom activities only. Successful teacher sees growth of learning activity of students as characteristic of personality through the chemistry education. There are two more powerful motives for learning activities. Learning information should be useful and interesting. If students have amount of chemical information they can be successful. For success of teaching chemistry we must align teaching methods with level of students' learning activity. It is the hypothesis of our research.

To develop of reproducing activity teachers should use such methods as didactic games. Teachers should show interaction between chemistry and human life. Contextual teaching is a powerful method of students' learning activities development. Some ways of contextual teaching are interaction chemistry with arts, mass-media. Students very like history of chemistry, chemical experiments. Students need positive emotions through learning, therefore they need teamwork. Teacher should prepare success of problem solving; therefore he should use visualization for understanding and prevention misconceptions. If students have some chemical knowledge, they have ability to solve chemical problems, to guess right ideas. Teacher can use heuristic discussions of chemical concepts with students of this level. Multilevel problems prepare success of solving problems for all students. Students have possibility to choice of solution methods. If students can use many methods visual methods for solving problems have approved. Creative activity students have strong will, ability to self-education and self-development. Creative activity students should set up chemical projects. These students should take part in chemical competitions, chemical conferences.

\section{Methodology of Research}

We carried out the pilot study of users' learning activity on chemical education websites. Methods of our research were studying of rating of chemical educational websites, studying websites statistics. We analyzed section "Chemistry" on Yandex-catalog. This section includes 92 chemical websites. 16 websites from them are designed for educational purposes. We study the website "Virtual Chemical School" counter statistics too.

\section{Results of Research}

"Chemistry \& Life" ranked first from educational websites. This website is virtual part of the Russian language journal «Chemistry \& Life". On pages of this website we can see interaction chemistry with other sides of human life. Citation index of this website is 1600. 
The website "Xumuk.ru" is second in the rating list of chemistry educational websites in Yandex-catalog. Citation index of this site was 1300. On the pages of website "Xumuk.ru" we can see interesting information for many students. The website has directories of organic and inorganic reactions; balancing chemical equations service; the directory of atomic structures; the physical quantities converter. On the pages of this websites we can see much useful information for chemistry students. There are chemistry knowledge bases: the encyclopedia of chemistry; the soviet encyclopedia, the handbook of chemical substances and others. Pages of the website include various useful theoretical materials for students: inorganic and organic chemistry; colloidal and biological chemistry and others. This website has the forum, as the virtual place where users can exchange opinions and ideas on chemistry. The forum is important part of websites for improving of attendance.

Textbook of organic chemistry is third in the rating list of chemistry educational websites at Yandex-catalog. Citation index of this site is 275. This websites has theoretical materials for secondary education students. There are materials from different sections of organic chemistry; recommendations for students to solve chemical problems, the flashalbum of organic compounds structures.

The Virtual Chemical Schools with citation index 170 ranked fourth among chemical education websites at Yandex-catalog. Most popular pages of Virtual Chemical Schools according to openstat.ru are atomic structure, recommendations for chemical calculations, nitrogen derivatives of hydrocarbons, problems with chemical reactions in water solutions, oxidation degree, hydrolysis of salts, chains of organic reactions.

Not only teenagers are users of the website, adults use it too. More part of these adults is teachers. It was found some gender differences. As table 2 shows, female gender users browsed the website nearly two times as much than male gender users. Girls (age 1218) use pages of the website nearly three times as much than this age boys (Table 1).

Table 1. Age and gender of users for maratakm.narod.ru - April 2012 (top.mail.ru).

\begin{tabular}{|l|c|c|c|c|}
\hline Age & Men & Percentage & Women & Percentage \\
\hline Younger than 12 & 324 & 1,28 & 297 & 1,17 \\
\hline $12-18$ & 3251 & 12,80 & 9670 & 38,08 \\
\hline $19-24$ & 1468 & 5,78 & 2259 & 8,90 \\
\hline $25-30$ & 615 & 2,42 & 764 & 3,01 \\
\hline $31-35$ & 351 & 1,38 & 753 & 2,97 \\
\hline $36-40$ & 601 & 2,37 & 1547 & 6,09 \\
\hline $41-45$ & 589 & 2,32 & 1034 & 4,07 \\
\hline $46-50$ & 361 & 1,42 & 527 & 2,08 \\
\hline$>50$ & 381 & 1,50 & 599 & 2,36 \\
\hline Total & 6670 & 37,9 & 10522 & 62,1 \\
\hline
\end{tabular}


Nearly $90 \%$ users browsed the website just one time per a month. We named them occasional users. The website has regular users too. These users browse the website 7 days per month or more. In April 2012 number of such users had 135 (0,28\%) (Table 2):

Table 2. Days on the website for maratakm.narod.ru - April 2012 (www.openstat.ru).

\begin{tabular}{|l|c|c|}
\hline $\begin{array}{c}\text { Number of da- } \\
\text { ys }\end{array}$ & Number of users & Percentage \\
\hline 1 & 44482 & 90,26 \\
\hline 2 & 3081 & 6,25 \\
\hline 3 & 756 & 1,55 \\
\hline 4 & 356 & 0,72 \\
\hline 5 & 181 & 0,37 \\
\hline 6 & 110 & 0,22 \\
\hline 7 & 52 & 0,11 \\
\hline 8 & 47 & 0,10 \\
\hline 9 & 36 & 0,07 \\
\hline
\end{tabular}

Every 8 from 10 users have duration of visits less than 10 seconds. About $8 \%$ users browsed the website pages more than 10 minutes (table 3).

Table 3. Duration of the website visits for maratakm.narod.ru - April 2012 (www.openstat.ru).

\begin{tabular}{|l|c|c|}
\hline Amount of time & Number of visits & Percentage \\
\hline $0-10$ seconds & 57303 & 80,85 \\
\hline $11-30$ seconds & 1169 & 1,65 \\
\hline $31-60$ seconds & 1137 & 1,60 \\
\hline $1-3$ minutes & 2375 & 3,35 \\
\hline 3-10 minutes & 3443 & 4,86 \\
\hline $10-30$ minutes & 4228 & 5,97 \\
\hline $\begin{array}{l}\text { 30 minutes and } \\
\text { over }\end{array}$ & 1223 & 1,73 \\
\hline
\end{tabular}

Most users opened only 1 page per visit. Some visitors browsed more than 5 pages of the website per visit (table 4).

Table 4. Views per visit for maratakm.narod.ru - April 2012 (www.openstat.ru).

\begin{tabular}{|l|c|c|}
\hline Views per visit & Number of users & Percentage \\
\hline 1 view & 55910 & 78,88 \\
\hline 2 views & 8446 & 11,92 \\
\hline 3 views & 2533 & 3,57 \\
\hline 4 views & 1181 & 1,67 \\
\hline 5 views & 657 & 0,93 \\
\hline 6 views & 449 & 0,63 \\
\hline 7 views & 341 & 0,48 \\
\hline 8 views & 212 & 0,30 \\
\hline 9 views & 179 & 0,25 \\
\hline
\end{tabular}

Attendance on the website of occasional users is essentially different on weekdays, but regular users browse website information every day. Saturday is weekday with the lowest activity of the website users (Figure 1). 


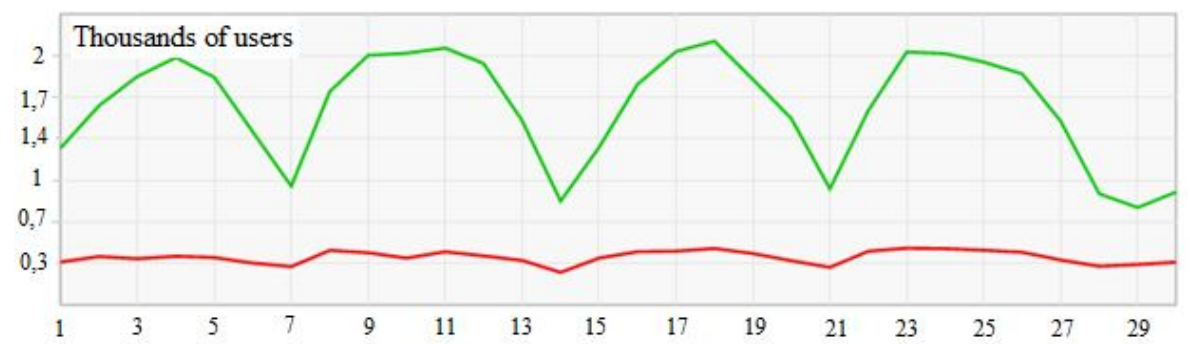

Figure 1: Regular and new users for maratakm.narod.ru - April 2012 (www.openstat.ru).

We studied learning activity of regular and occasional users in the days of preparation for the exam. It was found that regular users were most active on June 3 - the prior day to the exam. Occasional users have been most active on June 4 - the day of the exam (figure $2)$.

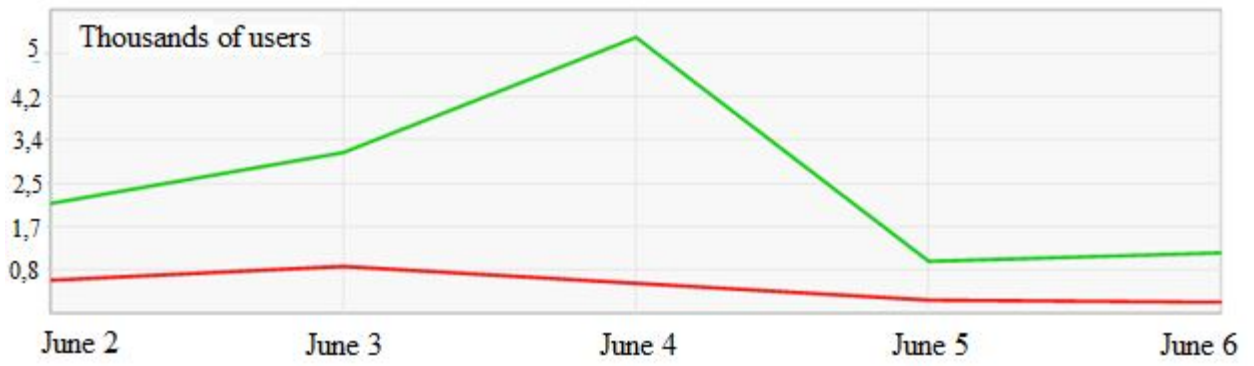

Figure 2: Regular and new users for maratakm.narod.ru - June 2-6 (www.openstat.ru).

For understanding this fact we had studied of the hourly users' activity three days at June. You can see statistics of hourly activity of the website users at June 3 in the following figure (3):

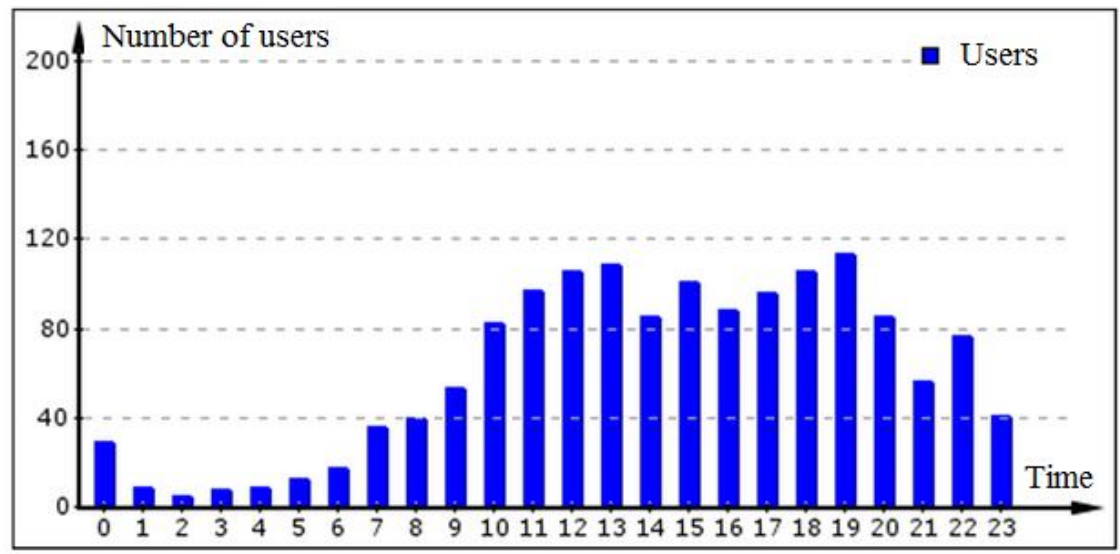

Figure 3: Regular and new users for maratakm.narod.ru - June 3 (my.counter.ua). 
On the day of the exam, we got the special diagram of the hourly users' activity. This diagram has maximum in the time period when the exam was held (figure 4):

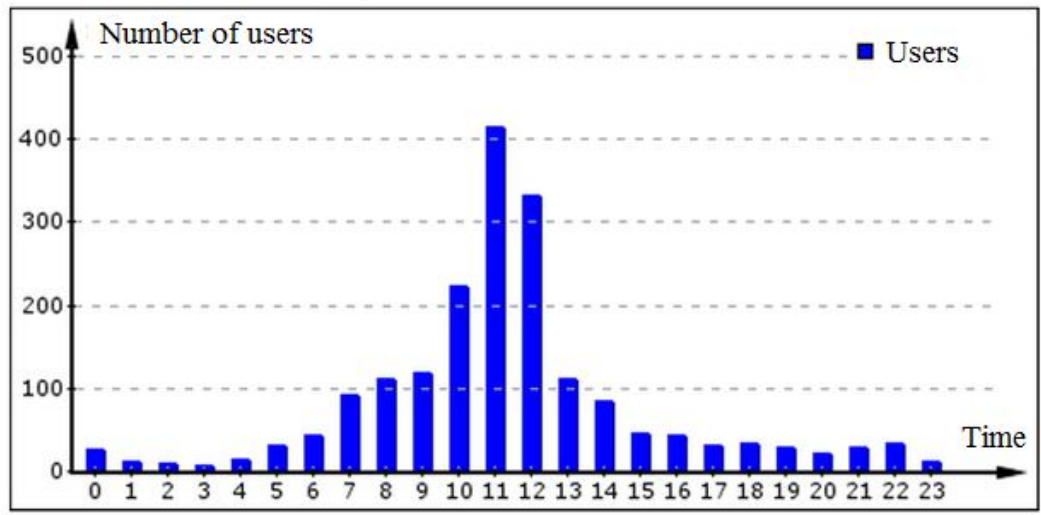

Figure 4: Regular and new users for maratakm.narod.ru - June 4 (my.counter.ua).

In the day after the exam hourly activity of the website users descended (Figure 5):

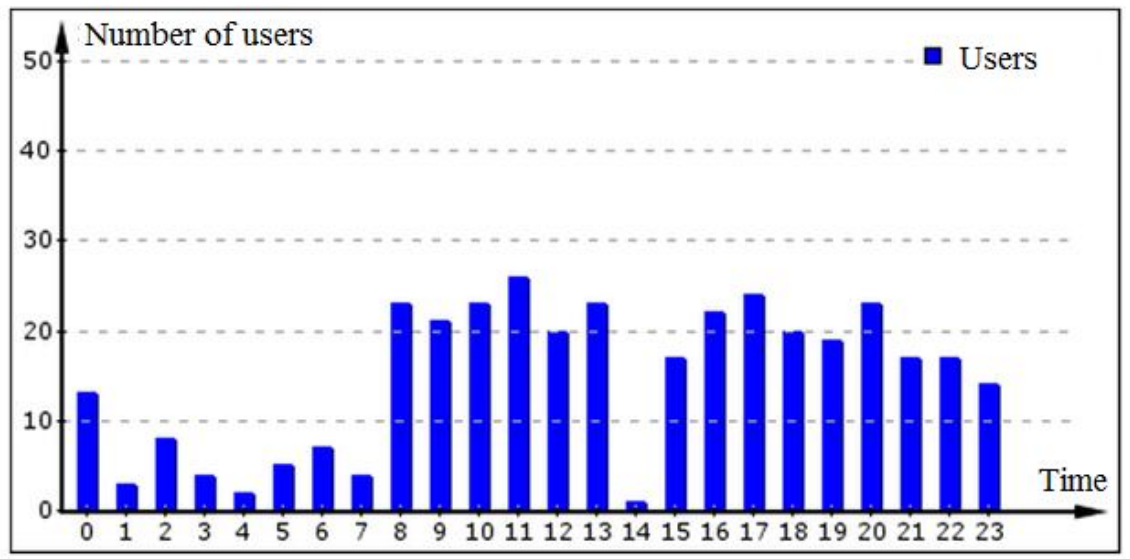

Figure 5. Regular and new users for maratakm.narod.ru - June 5 (my.counter.ua).

Most of website visitors are Russians. About 8\% Russian language users from others countries browsed the website (table 5).

Table 5. Users from all countries for maratakm.narod.ru - April 2012 (www.openstat.ru).

\begin{tabular}{|l|c|c|}
\hline \multicolumn{1}{|c|}{ Country } & Number of users & Percentage \\
\hline Russia & 64973 & 91,67 \\
\hline Ukraine & 2114 & 2,98 \\
\hline Kazakhstan & 1318 & 1,86 \\
\hline Byelorussia & 962 & 1,36 \\
\hline
\end{tabular}


ŠVIETIMAS: POLITIKA, VADYBA, KOKYBE்

EDUCATION POLICY, MANAGEMENT AND QUALITY

\begin{tabular}{|l|c|c|}
\hline USA & 511 & 0,72 \\
\hline Moldavia & 242 & 0,34 \\
\hline Sweden & 137 & 0,19 \\
\hline Uzbekistan & 115 & 0,16 \\
\hline Kyrgyzstan & 108 & 0,15 \\
\hline Latvia & 60 & 0,08 \\
\hline$\ldots$ & & \\
\hline Sum of all country users & 70877 & 100 \\
\hline
\end{tabular}

Most of the website users are residents of cities (table 6):

Table 6. Users from cities of Russia for maratakm.narod.ru - April 2012 (www.openstat.ru).

\begin{tabular}{|l|c|c|}
\hline \multicolumn{1}{|c|}{ City } & Number of users & Percentage \\
\hline Moscow & 10188 & 15,69 \\
\hline St. Petersburg & 4652 & 7,17 \\
\hline Krasnodar & 2618 & 4,03 \\
\hline Nizhny Novgorod & 2507 & 3,86 \\
\hline Samara & 2413 & 3,72 \\
\hline Ufa & 2508 & 3,86 \\
\hline Yekaterinburg & 2368 & 3,65 \\
\hline Kazan & 2032 & 3,13 \\
\hline Novosibirsk & 1837 & 2,83 \\
\hline Ulyanovsk & 1362 & 2,11 \\
\hline$\ldots$ & & \\
\hline Sum of all cities of Russia & 64917 & 100 \\
\hline
\end{tabular}

Table 7 shows most frequent search queries. These queries relate a preparation for the chemistry exam (table 7):

Table 7. Searching Query for maratakm.narod.ru - April 2012 (www.openstat.ru).

\begin{tabular}{|l|c|}
\hline \multicolumn{1}{|c|}{ Searching Query } & Number of users \\
\hline Chemical properties of nonmetals & 302 \\
\hline Oxidation degree & 289 \\
\hline Chemical properties of metals & 212 \\
\hline Chemical properties of oxides & 177 \\
\hline Hydrolysis of salts & 153 \\
\hline Preparation for the exam of chemistry & 143 \\
\hline Molecular structure & 129 \\
\hline Atomic structure & 129 \\
\hline Oxygen atoms in phenol molecule has & 128 \\
\hline Forms of chemical elements existence & 126 \\
\hline
\end{tabular}


The most frequently it was requested pages that users needed to prepare for the exam too (table 8):

Table 8. Most popular pages for maratakm.narod.ru - April 2012 (www.openstat.ru).

\begin{tabular}{|l|c|}
\hline \multicolumn{1}{|c|}{ Information from the more popular pages } & Number of users \\
\hline Atomic structure (index.htm) & 6036 \\
\hline Calculation formulas of substances & 3936 \\
\hline Nitrogen derivatives of hydrocarbons & 3793 \\
\hline Problems with calculations and reactions in solutions & 2465 \\
\hline Oxidation degree & 2147 \\
\hline Hydrolysis of salts & 1980 \\
\hline Organic chains & 1966 \\
\hline
\end{tabular}

Next part of Virtual Chemical School has address: him-school.ru. This site was developed on platform web 2.0. Therefore the website has many new opportunities. One of these opportunities is registration of users. The website has top-list of best student for develop of users' learning activity. The forum was created on the website. Users can ask and write comments. The students get an answer on their e-mail too. One of the new opportunities is multimedia lessons. Students can take texts of problems from the municipal stage nationwide Chemistry Competitions. On the website students can use tests for training. We've got rating of pages from chemical websites. Contextual problems and chemical competitions took first place on the rating. Multimedia lessons and tests are most popular pages of the website.

\section{Discussion}

Statistics shows that most visitors use the website only for searching information not for learning. For improvement in learning activity, users need motivation that is the basis of any activity. It is important that this motivation was internal. In the Russian fairytale that reflects the wisdom of the people, it was told: «First, feed me, give me a drink, and lay me to sleep, and just then - ask me!". Most users firstly need fun for study. It is necessary to integrate this fun into chemical theory for improvement in users' learning activity we should (Akhmetov, 2012):

- to put on a website video clips with interest chemical experiments:

- to put on a website chemistry educational games;

- to create applications for teamwork learning;

- to combine chemical theory with story about history of chemistry, with art (poetry, prose, movie clips, painting, sculpture), with other subjects (physics, mathematics, biology and others), with media (TV, radio, Internet, magazines, newspapers);

- to demonstrate link between chemical knowledge and everyday life.

Any theory is a scientifically valid way to solve problems of life. Therefore, a theory without practice is useless, and a theory as a way to solve practical problems is significant and full of meaning. Before learning a theory, users should meet problems that this theory allows to solve it. So this theory will be important, understandable and easy to learn (Akhmetov, 2010). 
For best learning users need a multiple repetition of one topic, by this way they can achieve deeper knowledge. Learners need to use technology of deep learning. They in their mind have seen substances, and their structures; be able to demonstrate structures of substances by using models and formulas; have understand formulas and know how to describe their internal representations by words. Visual, auditory, kinesthetic, digital sense of representation should be linked into a common image (Akhmetov et al., 2010, p.24-25)

\section{Conclusions}

The hypothesis was confirmed. For improving users' learning activity information of website should be useful and interesting. This chemical information will prepare success of learning activity as basis of development learning activity.

For improving online learning activity it is need to:

- put an information on website that can develop users' interest to chemistry;

- give users opportunity to choose between theory and practice of chemistry;

- achieve deep knowledge by combining of visual, auditory, kinesthetic sense with formulas in their mind for whole imagination;

- integrate chemical problems with life situations, history of chemistry, mass-media, other subjects and sides of human life.

For detailed understanding of problem we need additional research

\section{Acknowledgements}

I'd like to thank my family: my wife and my son for their support throughout the years. Special thanks to my son for web design.

\section{References}

Akhmetov, M. (2010). Chemical education in secondary school: contents of cognitive problems. In. International scientific-practical conference "Chemistry Education 2010". Riga.

Akhmetov, M., Pilnikova, N., Ksenofontova G. (2010). Study of the Effect of a Visual Representation on Students' Chemical Calculations. 10th European Conference on Research in Chemistry Educations: Books of Abstracts: Krakow, p. 24-25.

Akhmetov, M. (2012). The Development of Students' Learning Activity Through the Teaching Chemistry. Gamtamokslinis ugdymas / Natural Science Education, 2 (34), 43-59.

Received 22 October 2012; accepted 30 November 2012

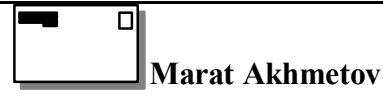

Lecturer, Head of Department, Teacher Professional Skills Advancement Institute, Ulyanovsk, Russia.

E-mail: maratakm@ya.ru

Website: http://maratakm.narod.ru/ 